\title{
AC 2009-1685: HANDS-ON LAB DEMONSTRATION TO TEACH HOW MECHANICAL PROPERTIES CHANGE DUE TO COLD WORKING AND RECRYSTALLIZATION
}

Daniel Magda, Weber State University 


\title{
Hands on Lab Demonstration to Teach how Mechanical Properties Change Due to Cold Working and Recrystallization
}

\begin{abstract}
Laboratories that employ hands-on demonstration to change material properties play an important role in understanding why materials are selected for different design specifications. Engineering students take courses in mechanics of material, machine design, finite element analysis and capstone senior projects. These courses require students to call out and specify the best and least expensive material according to some type of chemical, physical or mechanical loading conditions. Students should understand the way a material behaves in service depends upon its alloy composition, crystalline structure, manufacturing process and heat treat condition. This paper is written after developing a hands-on material lab that teaches engineering students how cold work and recrystallization processes affect material properties. The driving force for this hands-on lab came from the "ABET course level loop assessment action" outlined in appendix A. Its main focus is with yellow brass and copper, however, other metallic materials can be used and explored by the same procedure outlined in the lab handout. The first part of the lab requires students to set up a heat treat furnace. They anneal yellow brass and measure hardness values at different soak times. By plotting the data of hardness versus log time in minutes will show the three unique stages of the recrystallization process. The second section of the lab teaches how the cold working process changes mechanical properties. Students receive test coupons of copper to cold work to different percentages. Hardness and dimensional values are measured and the data are plotted to generate material behavioral curves. A series of questions in the lab handout helps reinforce the theory taught in the class room to this hands-on learning process.
\end{abstract}

\section{Introduction}

Metals are commonly used in many design applications because of their strength and ductility properties. Cast irons, tool steels and ceramics are some examples of materials that can exhibit high strength but very low ductility. These materials have very little to no plastic region on a stress strain diagram. Ceramics and glasses can even fracture well below the ultimate tensile strength of the material. This is caused by stress concentrations and the lack of ductility that does not allow the state of stress to relax within the geometric discontinuities.

Ductility is a measure of plastic deformation and is a required material property for joining, extruding, swedging, drawing and forging operations. Introducing the metal to some mechanical and/or thermal manufacturing processes can easily alter the material properties of strength, hardness and ductility. The processes of work hardening at room temperature and annealing are two common manufacturing processes that typically change mechanical properties of metallic materials. 
Forming operations can be subdivided into hot work at elevated temperatures and cold work at room temperature. Cold work materials not only change the material shape but also change's microstructure and mechanical properties. ${ }^{1}$ Dislocations move and get entangled at barriers to increase strength and hardness. As the percent of cold work increases the material becomes so hard that it starts to crack because of low ductility. To reintroduce ductility back into a material, students learn about the annealing processes. This process will reverse the effects of cold work by soaking the cold work material in a furnace at a recrystallization temperature for a specified time. The cold work material will typically go through a three-part process of recovery, recrystallization and then grain growth. The final properties will exhibit lower strength with high ductility and a material with large grains in its microstructure.

These two processes of cold work and annealing are discussed further in this paper and will focus on the effect of cold work tough pitch copper 11000 and annealing yellow brass 26000 . Students conduct a laboratory exercise to plot material behavioral curves of material properties to reinforce the theory taught in class.

\section{Copper and Copper Alloys}

Copper was first discovered about 10,000 years ago where it was particularly used in pure form for decorative parts. ${ }^{1}$ Not until the turn of the Bronze age that copper was alloyed with tin to improve material properties. Today copper is alloyed with many different elements to achieve desirable engineering properties. It ranks third behind iron, steel and aluminum in production and consumption. Copper is widely used in many applications because it is easy to fabricate and cast into many products. Approximately $80 \%$ of all copper produced is pure. ${ }^{2}$ This copper is mostly used in applications of electrical conductivity, thermal conductivity and corrosion resistant parts. The alloyed coppers which contain the brasses and bronzes are typically used for heat exchangers, automobile radiators and home heating water systems. Since copper has excellent ductility, this property makes it workable and formable. These cold work coppers typically consists of small gears, fasteners, springs, electrical contacts and other hardware where higher strength properties are required.

\section{Theory of Cold Work}

\section{Cold Work $=$ Shape Change ${ }^{3}$}

Cold work refers to the reduction of size in a material due to some rolling, forging, extrusion, swedging or drawing operation. A rolling operation showing shape change of grains is shown in Figure 1. Basically cold work is an addition of energy to the material in the form of strain. This shape changing process is typically done below the recrystallization temperature. Plastic deformation will change the microstructure of grain size, orientation and dislocation density. These internal changes will have an increase effect on strengthening the mechanical properties of the material. At low temperatures a cold work fine grain material is harder and stronger as compared to course grain material. However, the opposite occurs at elevative temperatures where atoms start to move and grain boundaries are a source of weakness. 
Plastic deformation of a material depends on its crystal structure. Materials with a hexagonal close pack (HCP) crystal structure will have a low strain hardening coefficient $(n)$ and will respond poorly to cold work. While face center cubic (FCC) materials respond quite well to strain hardening. This is demonstrated in Figure 2. The strain hardening coefficient $n$ in equation one is determined by the slope of the true stress vs. true strain curve using a log scale. The variable $\mathrm{K}$ is equal to the stress when the true strain is equal to 1 .

Face center crystals plastically deform and work harden well because they have at least five independent slip systems where dislocations can easily move. ${ }^{4}$ As dislocations move their ends may be pinned by defects in the lattice as they encounter obstacles or barriers. When this happens the dislocation bends to form a loop and another dislocation is created. This increases the dislocation density. Not only due dislocations move on closely spaced slip lines but now they interfere with other moving dislocations to cause networks of entanglements or road blocks within the crystal lattice. This increase in dislocation density and entanglements increase the critical shear stress required for slip on a crystal plane. The result of this process increases the mechanical strength properties while decreasing ductility in the material.

$$
\log \sigma_{t}=\log K+n \log \varepsilon_{t} \quad \text { or } \quad \sigma_{t}=K \varepsilon_{t}^{n}
$$

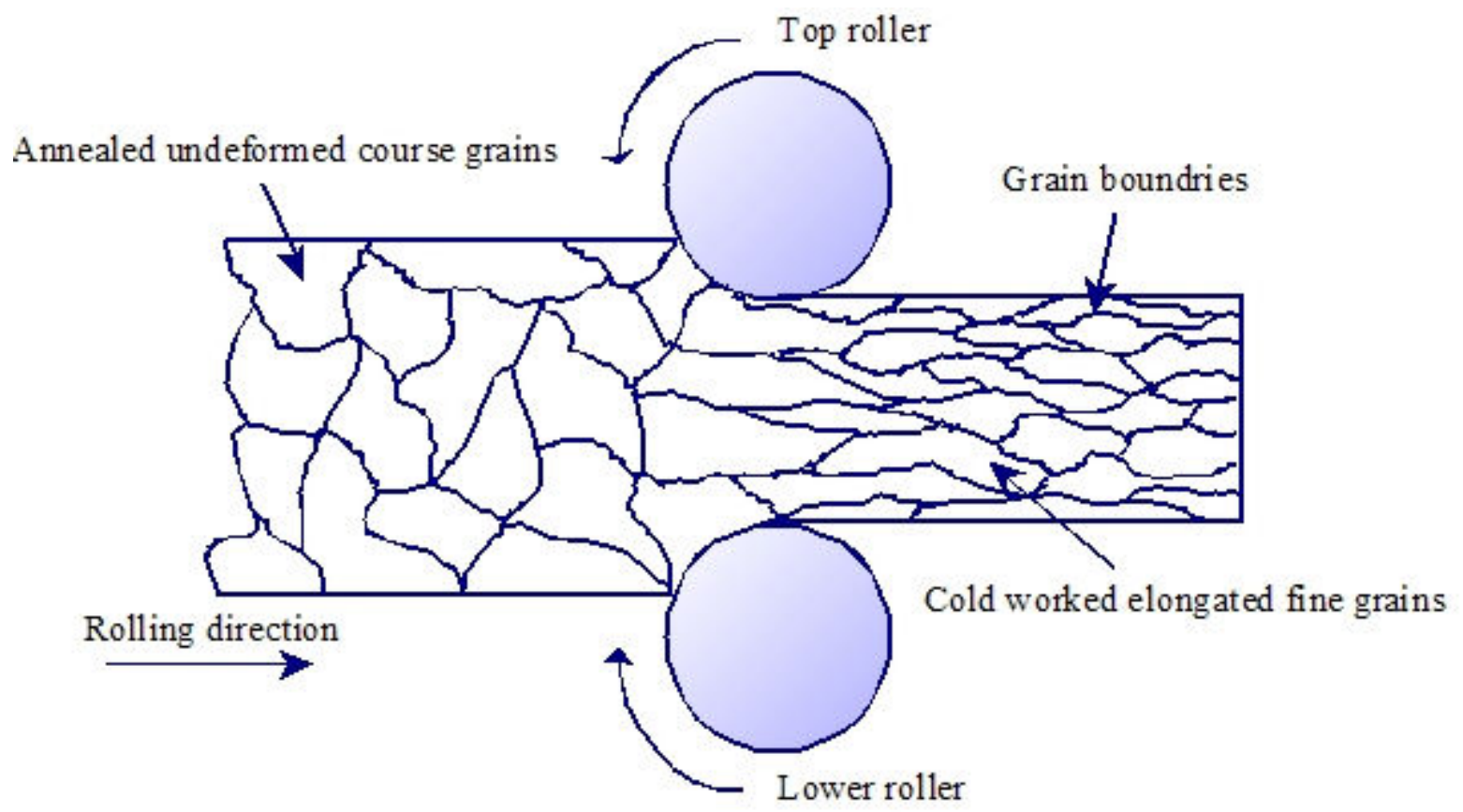

Figure 1. Rolling operation showing deformation of grains. 


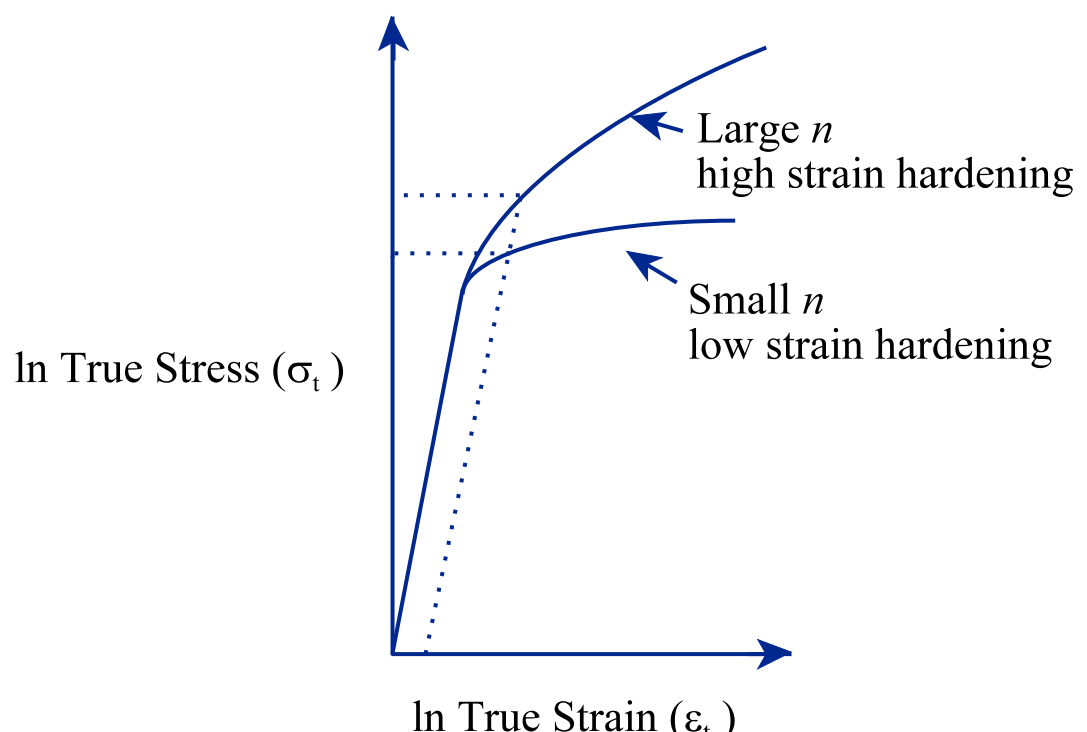

Figure 2. True stress vs. true strain diagram.

\section{Theory of Annealing}

Cold work materials have dislocation cell structures that are mechanically stable. However, these same structures are not thermodynamically stable. Metallic materials that have been cold work can be returned to their original soft state by a heat treatment process called annealing. The heat treatment process produces a strain-free state that improves ductility and toughness while decreasing mechanical strength properties.

The heat treatment process of annealing a cold work material is a function of soak time and furnace temperature. This process can be subdivided into three distinct processes that consists of recovery, recrystallization and grain growth. Recovery is a low temperature heat treatment process that restores physical properties with no observable change in microstructure. In a cold work microstructure the deformed elongated grains contain some large amounts of entangled dislocation networks and point defects. As we approach the recrystallization temperature dislocations are not eliminated but they move and are rearranged to decrease and eventually remove residual stresses. Additional to this, electrical and thermal conductivity properties that are sensitive to point defects are also restored.

The stored energy from cold work is the driving force for recovery and recrystallization to take place. At the recrystallization temperature $T_{\mathrm{R}}$ the original cold work grains start to transform to a set of strain-free grains through a nucleation process. This temperature $T_{\mathrm{R}}$ given in degree's kelvin is around 30 to 60 percent of the material melting temperature. At this temperature dislocations start to polygonized and some are swept away and annihilated. This process of 
polygonized dislocations can be seen in Figure 3. ${ }^{5}$ The recrystallized material having a decrease in dislocation density promotes higher ductility and lower strength properties. Typically there are six variables that affect recrystallization: time, temperature, composition, initial grain size, amount of prior deformation and the amount recovery and dislocation polygonization prior to the start of the recrystallization process.

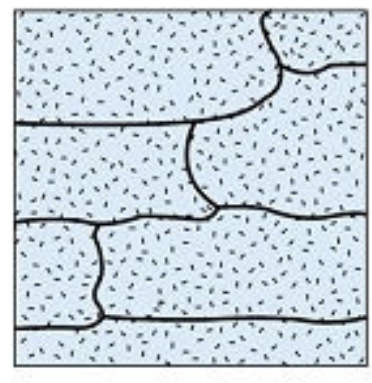

(a)

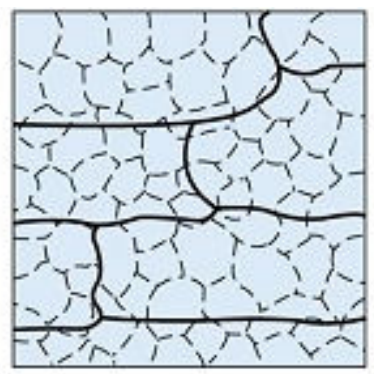

(b)

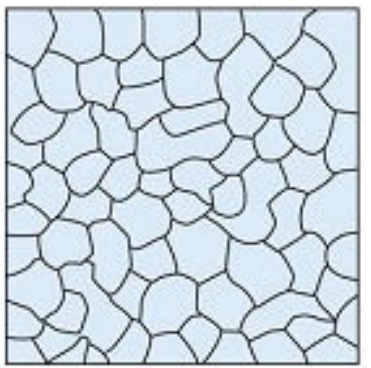

(c)

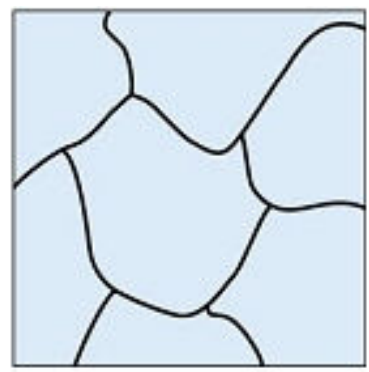

(d)

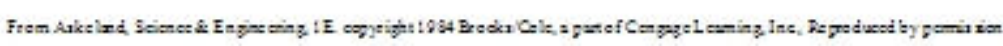

Figure 3. The effect of annealing on the microstructure (a) cold work, (b) after recovery, (c) after recrystallization, (d) after grain growth.

If the material is heated above the $T_{\mathrm{R}}$ temperature grains will tend to grow in size. Diffusion of atoms into the grain at high temperatures causes grain boundaries to move. Some grains grow at the expense of others therefore reducing grain boundary energy. The driving force for grain growth is the decrease in free energy associated with the grain boundary area at the expense of increase area of the grains. As grain growth continues its size is restricted by fine dispersion of second phase particles in the microstructure.

\section{Engineering Design Consideration of Cold Work and Annealed Materials}

Engineering and technology students learn about design in many courses. However, when it comes to select materials for the project, they should have the knowledge of how the material will respond to some specific loading criteria or manufacturing process. Mechanical and physical properties of materials will respond differently to different loading scenarios and environments. Cold work strain hardened materials are a good choice in design when strength to weight ratio is a specification. You can easily produce a smaller part that supports higher loads. However, caution should be taken with these materials if they are exposed to high temperatures. At elevative temperatures they can recrystallize and become weaker in service. Cold work materials with finer grain structure and more grain boundary area works better in time dependent failure modes like fatigue, creep and stress corrosion cracking. And when it comes to manufacturing by machining operations cold work materials produce a discontinuous chip because of less ductility in the material. Very typically the cold work and annealing process work in cycles to improve either strength or ductility properties. For students to understand the effects of materials on design a hands on lab was developed. In this lab students anneal and cold work materials then take measurements to plot the results showing material behavior curves. 


\section{Materials Laboratory}

\section{Cold Work \& Recrystallization of Copper Alloys}

Objective To determine the effect of different percentages of cold work and recrystallization have on mechanical properties of copper alloys. The properties tested and measured are ductility, hardness, and strength.

Background Study and review the theory and procedures for hardness and tensile testing. Also review the section in your materials book on cold work and annealing processes. Have a good understanding on the effects of dislocations and microstructure pertaining to cold work and recrystallization.

Materials Tough pitch copper 11000 and yellow cartridge brass 26000 (70/30).

Procedure Part 1 recrystallization of yellow brass. Set heat treatment furnace to $800{ }^{\circ} \mathrm{F}$ prior to start of the lab. Eight coupons of as received yellow brass will be used in this experiment. First, measure the initial hardness of the brass using the Rockwell $\mathrm{R}_{\mathrm{f}}$ scale. Place brass coupons in the $800^{\circ} \mathrm{F}$ furnace for the various times followed by water quenching and then hardness measurement. Logarithmic times are convenient, such as 2, 4, 6, 8, 16, 32 and 64 minutes. Start the 64 and 32 minute specimens to save time. Plot the data of hardness $\mathrm{R}_{\mathrm{f}} \mathrm{vs}$. annealing $\log$ time. The ordinate hardness range is from the $\mathrm{R}_{\mathrm{f}}$ of the annealed specimen to the $\mathrm{R}_{\mathrm{f}}$ of the as received brass. The abscissa runs from 1 to 64 minutes.

Part 2 cold work of tough pitch copper. Seven annealed coupons of tough pitch copper are provided. Measure and record the width, length and thickness of each test coupon. Cold roll six of the seven coupons to $10 \%, 20 \%, 30 \%, 40 \%, 50 \%$ and $60 \%$ reduction in thickness. This will correspond to the percent of cold work. Crossroll the coupons in order to keep them flat. Measure the Rockwell hardness $\mathrm{R}_{\mathrm{f}}$ in three different locations on the seven copper coupons. If test coupons become to thin and bulging occurs on the backside change to the superficial T30 hardness scale. ${ }^{6}$ Then conduct a tensile test on each of the seven coupons to measure mechanical properties. Plot the data of hardness vs. \% cold work, tensile strength vs. $\%$ cold work, yield strength vs. $\%$ cold work, $\%$ elongation vs. $\%$ cold work and tensile strength vs. \% elongation.

Report Find annealing curves and microstructure pictures in the American Society for Metals Handbooks (ASM) for yellow brass. Show on your graph of hardness vs. log annealing time the areas of recovery, recrystallization and grain growth. Also, include sketches of the microstructure for each zone. 
Equations The equations for the percent of cold work and percent elongation are listed where the original area $A_{\mathrm{o}}$ is equal to $\mathrm{T}$ times $\mathrm{W}$. Assume the width $\mathrm{W}$ remains constant through the reduction process.

\%coldwork $=\frac{A_{o}-A_{f}}{A_{0}} \times 100=\frac{T_{o}-T_{f}}{T_{o}} \times 100$

$$
\text { \%elongation }=\frac{L_{f}-L_{o}}{L_{o}} \times 100
$$

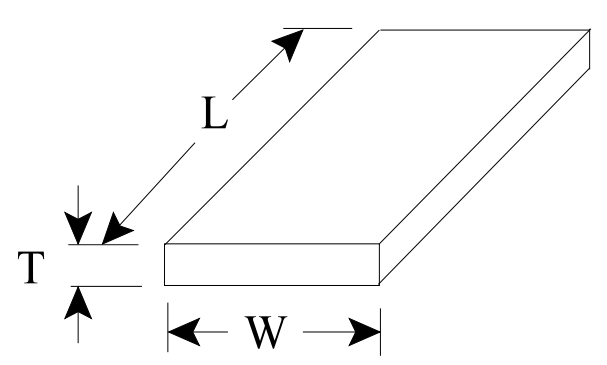

Figure 4. Test coupon geometry for cold work. 


\section{Lab Data Sheet}

Part 1 Recrystallization data

Material__ Yellow brass $(70 / 30)$

Annealing Temperature $\quad 800^{\circ} \mathrm{F}$

\begin{tabular}{|c|c|r|r|r|r|}
\hline Time (min) & Log time & \multicolumn{3}{|c|}{ Hardness (HRF) } & Avg. (HRF) \\
\hline & 0 & 100.6 & 100.8 & 100.4 & 100.6 \\
\hline 2 & .30 & 98.5 & 98.5 & 98.5 & 98.5 \\
\hline 4 & .60 & 88.2 & 88.6 & 88.7 & 88.5 \\
\hline 8 & .90 & 74.5 & 74.5 & 79.0 & 76.0 \\
\hline 16 & 1.2 & 75.8 & 75.6 & 76.0 & 75.8 \\
\hline 32 & 1.5 & 75.4 & 75.4 & 75.4 & 75.4 \\
\hline 64 & 1.8 & 75.1 & 75.7 & 75.1 & 75.3 \\
\hline
\end{tabular}

Part 2 Cold work data

Material Tough pitch copper 11000

\begin{tabular}{|c|r|r|r|r|r|}
\hline $\begin{array}{l}\text { Thickness } \\
\text { (in) }\end{array}$ & \% Cold work & \multicolumn{3}{|c|}{ Hardness (HRF) } & Avg. (HRF) \\
\hline .0920 & 0.0 & 39.9 & 39.9 & 41.2 & 40.0 \\
\hline .0856 & 6.8 & 61.1 & 61.8 & 61.9 & 61.6 \\
\hline .0728 & 21.0 & 85.4 & 85.0 & 85.8 & 85.4 \\
\hline .0640 & 30.5 & 88.7 & 88.1 & 88.7 & 88.5 \\
\hline .0549 & 41.2 & 91.0 & 91.0 & 91.0 & 91.0 \\
\hline .0460 & 50.0 & 92.2 & 93.1 & 92.5 & 92.6 \\
\hline .0368 & 60.0 & 94.2 & 93.9 & 93.9 & 94.0 \\
\hline
\end{tabular}




\section{Lab results}
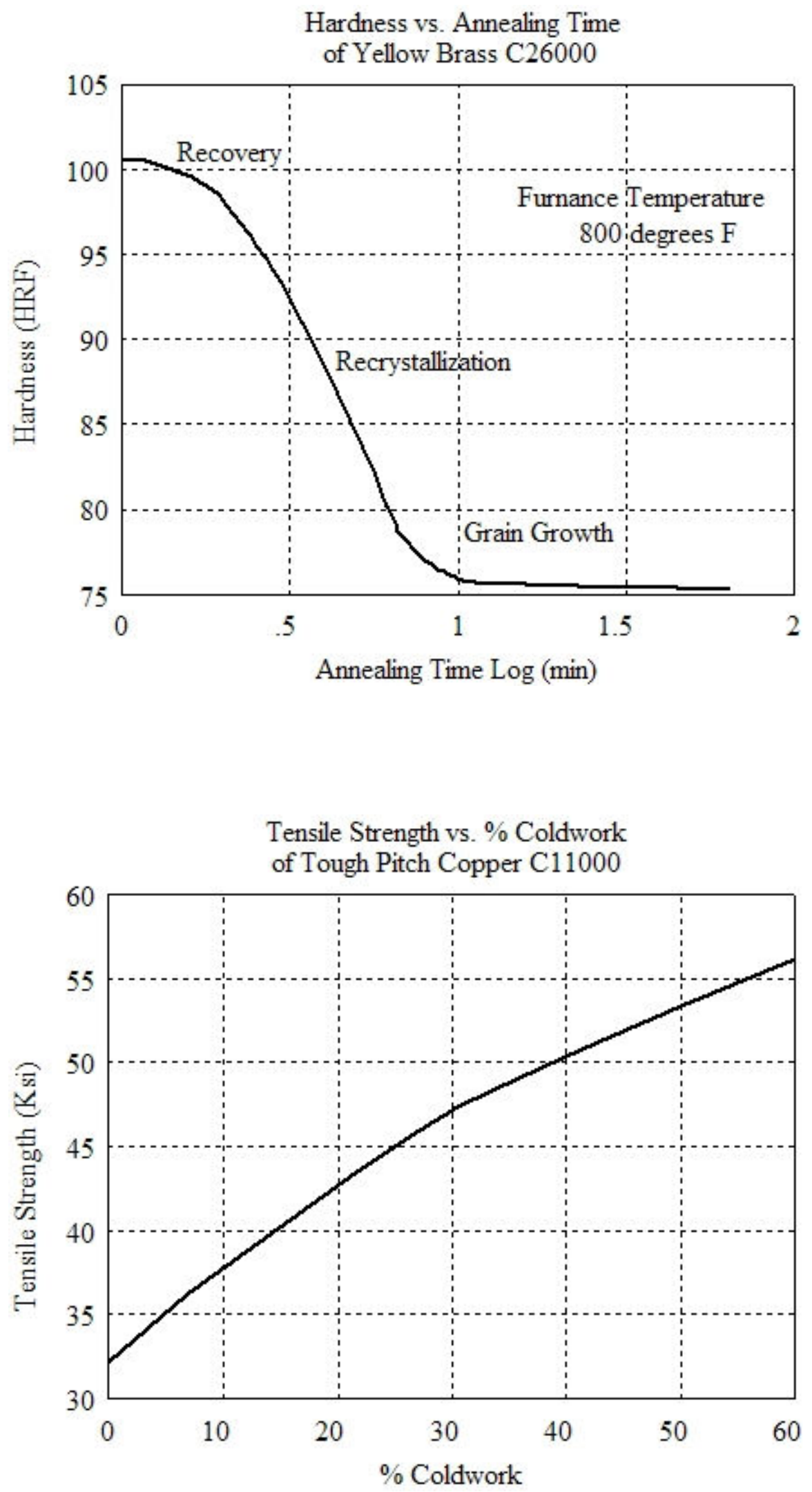

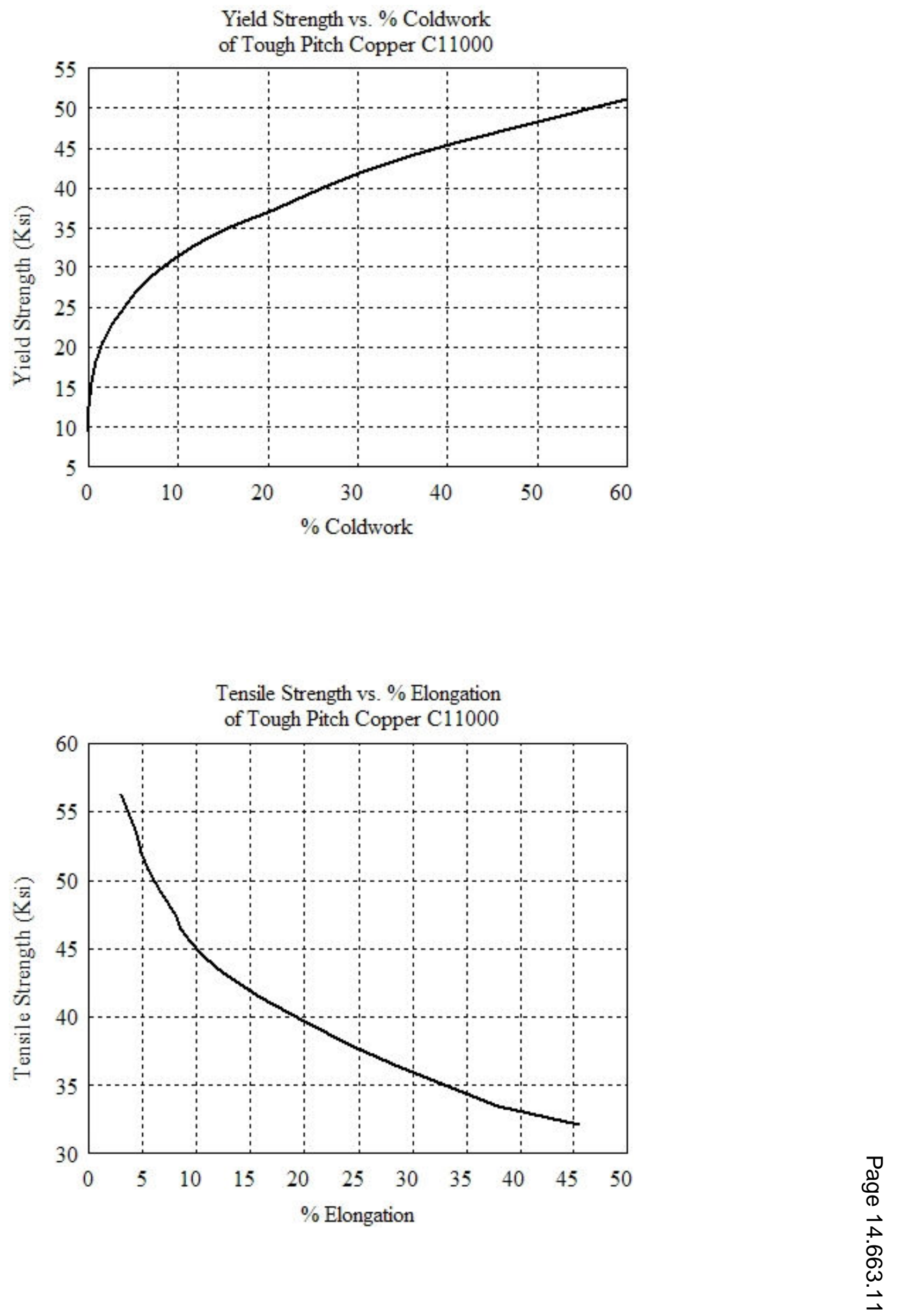

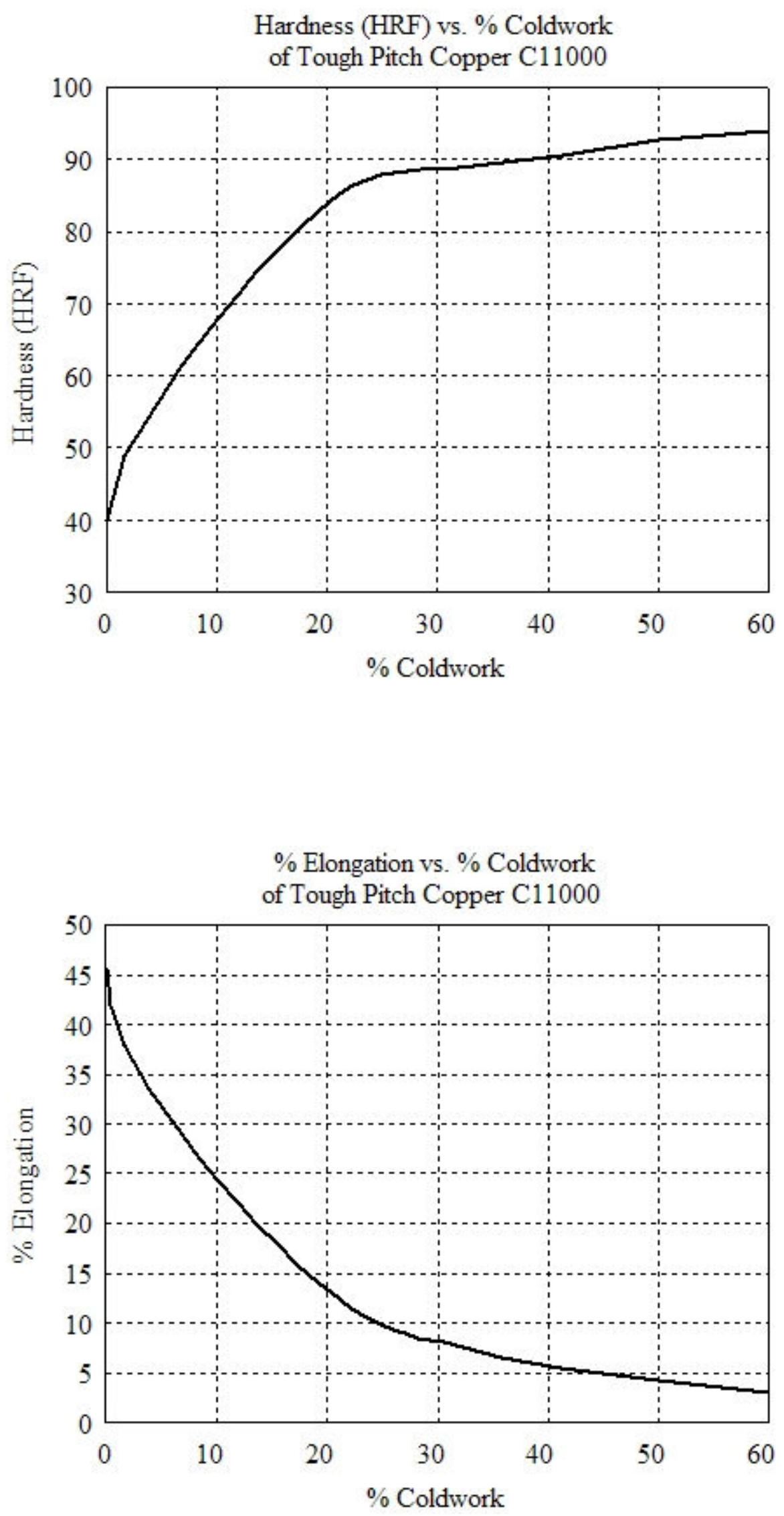

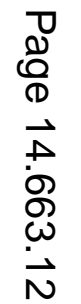




\section{Lab questions}

1. What is the driving force for recovery, recrystallization and grain growth?

2. What is the mechanism for recovery, recrystallization and grain growth?

3. What are the primary results from recovery, recrystallization and grain growth?

4. Explain what happens to dislocations and the relationship of mechanical properties during the annealing and cold work processes?

5. Explain what happens to grain size and shape and the relationship of mechanical properties during the annealing and cold work processes?

6. At room temperature is it better to select a course grain or fine grain material for load carrying parts? What about at elevative temperatures? Why?

\section{Summary}

This hands-on lab has been implemented into the MET materials class to facilitate the theory taught in the classroom. The tools of assessment are the direct opinion from students commenting on how they understand and learn through practical experiences. Increase enthusiasm discussing materials in the classroom. Finally compared with previous semesters there have been more detailed complete answers on exams that involve questions about cold work and recrystallization throughout the course. Overall this lab addition has been a successful learning tool for students.

\section{References}

1. Elements of Material Science and Engineering, Lawrence H. Van Vlack, Pub. Addison-Wesley, Fourth Edition, 1980, Pg. 207-207.

2. ASM Specialty Handbook, Copper and Copper Alloys, ASM International the Materials Information Society, Ed. J. R. Davis and Associates, 2001, pg. 8,9.

3. Engineering Materials Properties and Selection, Kenneth G. Budinski, Michael K. Budinski, Pearson Prentice Hall, $8^{\text {th }}$ ed., 2005, pg. 631.

4. Introduction to Engineering Materials, $2^{\text {nd }}$ Ed.,George Murray, Charles V. White, Wolfgang Weise, CRC Press, London, New York, 2008, Pg. 137-145.

5. Materials Science and Engineering Series, Mechanical Metallurgy, George E. Dieter, McGraw -Hill Series in Materials Science and Engineering, 1976,pg. 192.

6. The Science and Engineering of Materials, Donald R. Askeland, Brooks/Cole Engineering Division, Wadsworth Inc., Belmont California, 1984, Pg. 221.

7. Fundamentals of Rockwell Hardness Testing, Wilson Instruments, Binghamton, New York, Instruments for Quality Control, 1988. 


\section{Appendix A}

\begin{tabular}{|c|c|c|c|c|}
\hline \multicolumn{5}{|c|}{ ABET Course Level Loop Assessment Action 2008} \\
\hline \multirow{2}{*}{\multicolumn{2}{|c|}{$\begin{array}{l}\text { Course: MET } 3150 \\
\text { Materials }\end{array}$}} & \multirow{3}{*}{$\begin{array}{l}\text { Faculty Responsible for } \\
\text { Survey and Action Items: } \\
\text { Prof. Magda }\end{array}$} & \multirow{3}{*}{$\begin{array}{l}\text { Faculty Responsible for } \\
\text { Proposed Future Action: } \\
\text { Prof. Magda }\end{array}$} & \multirow{3}{*}{$\begin{array}{l}\text { Faculty Responsible for } \\
\text { Implemented Action: } \\
\text { Prof. Magda }\end{array}$} \\
\hline & & & & \\
\hline \multicolumn{2}{|c|}{ Semester: Spring } & & & \\
\hline & $\begin{array}{l}\text { Source of } \\
\text { Information }\end{array}$ & $\begin{array}{l}\text { Item for which action is } \\
\text { implemented or proposed }\end{array}$ & $\begin{array}{l}\text { Proposed Future action on } \\
\text { Item }\end{array}$ & $\begin{array}{l}\text { Implemented Action on } \\
\text { Item }\end{array}$ \\
\hline 1 & $\begin{array}{l}\text { Student } \\
\text { Questionnaire }\end{array}$ & $\begin{array}{l}\text { Would like to learn more } \\
\text { through hands-on } \\
\text { laboratory experiences } \\
\text { that complements the } \\
\text { theory taught in class }\end{array}$ & $\begin{array}{l}\text { Develop additional lab } \\
\text { work to measure the } \\
\text { changes in mechanical } \\
\text { properties due to heat } \\
\text { treatment and cold work } \\
\text { processes }\end{array}$ & $\begin{array}{l}\text { Develop a lab that student } \\
\text { conduct that shows the } \\
\text { relationship of cold work } \\
\text { and recrystallization have } \\
\text { on mechanical properties } \\
\text { where the students are } \\
\text { measuring these } \\
\text { properties }\end{array}$ \\
\hline 2 & Course Evaluations & $\begin{array}{l}\text { More time needed to } \\
\text { complete the exam's }\end{array}$ & $\begin{array}{l}\text { Reduce the number of } \\
\text { problems on the exam's }\end{array}$ & $\begin{array}{l}\text { Add additional exam to } \\
\text { compensate for the } \\
\text { reduction of exam } \\
\text { problems }\end{array}$ \\
\hline 3 & $\begin{array}{l}\text { Prof. Magda } \\
\text { Observations }\end{array}$ & $\begin{array}{l}\text { Students needs more } \\
\text { practical discussions on } \\
\text { material selection }\end{array}$ & $\begin{array}{l}\text { More show and tell of } \\
\text { failed machine parts }\end{array}$ & $\begin{array}{l}\text { Bring into the class failed } \\
\text { machine parts and have } \\
\text { open discussion what } \\
\text { went wrong in selecting } \\
\text { the material based on } \\
\text { manufacturing and heat } \\
\text { treatment processes. }\end{array}$ \\
\hline
\end{tabular}

